\title{
PROFITABILITY AND RESOURCE USE EFFICIENCY OF BUCKWHEAT (FAGOPYRUM ESCULENTUM MOENCH) PRODUCTION IN CHITWAN DISTRICT, NEPAL
}

\author{
S.C. Dhakal ${ }^{1}$, P.P. Regmi ${ }^{2}$, R.B. Thapa ${ }^{3}$, S.K. Sah $^{4}$ and D.B. Khatri-Chhetri ${ }^{5}$
}

\section{ABSTRACT}

The study was designed to determine the profitability and resource use efficiency of buckwheat production in Chitwan. The study used 42 buckwheat growers from 300 farmers adopting different pollinator friendly practices. Descriptive and statistical tools including Cobb-Douglas production function were used on data collected from structured interview schedule to accomplish the objectives. The benefit cost ratio (1.25) indicates that buckwheat production was profitable. The magnitude of regression coefficients of buckwheat implied that use of tractor and nutrient cost had significant positive effects on gross return. According to estimated allocative efficiency indices, it is suggested to reduce labor and seed cost by about $148 \%$ and $143 \%$ respectively and; increase the use of tractor and nutrient inputs by about $63 \%$ and $19 \%$ respectively. Extension of modern technologies with adjustment on resource use explains for increase in return and profit from buckwheat production which indirectly promotes and ensure forage for pollinators in study area.

Key words: Allocative efficiency, buckwheat, pollinators, profitability, resource use efficiency

\section{INTRODUCTION}

Buckwheat (Fagopyrum esculentum Moench, family Polygonaceae ) is one of the important under exploited crops of Nepal and is popularly known as "Pseudo cereal". It is a minor crop occupying 10,339 ha of land area, majority of which lies in mid-hills, with the production of $10,021 \mathrm{t}$ and productivity of $0.97 \mathrm{t} / \mathrm{ha}$ (MoAD, 2012). It contains best high quality digestible protein with balanced amino acids and minerals (Eggum et al., 1981). It is free from cholesterol and fits the modern desirable form of diet (Francischi et al., 1994). Buckwheat is cultivated for its use as staple food, animal feed, vegetable, soup, beverage and medicine. Area under buckwheat in Chitwan in 2014 was 1500 ha and productivity was $0.8 \mathrm{t} / \mathrm{ha}$ (DADO, 2014).

Buckwheat is cross pollinated and an entomophilic plant, which is pollinated mainly by honey bee. The cultivation of buckwheat along with beekeeping could produce 50 to $100 \mathrm{~kg}$ of honey per ha due to its extended flowering period for more than 30 days (Rajbhandari, 2010). Aryal et al. (2014) reported that quality and quantity of buckwheat production was improved with bee pollination in a study at Chitwan and suggested buckwheat production along with bee farming and conservation of natural pollinators.

\footnotetext{
${ }^{1}$ Shiva Chandra Dhakal, Asst. professor, AFU, Rampur, Chitwan, Nepal, Email:nepal_dhakal@ymail.com

2 Punya Prasad Regmi, Professor (Agricultural Economics), TU, IAAS, Rampur, Chitwan, Nepal

${ }^{3}$ Resham Bahadur Thapa, Professor (Entomology), TU, IAAS, Rampur, Chitwan, Nepal

${ }^{4}$ Shrawan Kumar Sah, Professor (Agronomy), AFU, Rampur, Chitwan, Nepal

${ }^{5}$ Dilli Bahadur K.C., Seed Value Chain and Marketing Expert at CIMMYT International, Nepal
} 
Pollination is a critical link in the functioning of ecosystems and it is essential for the production of a wide range of crops. Several studies have shown that pollination makes a very significant contribution to the agricultural production of a broad range of crops, in particulars fruits, vegetables, fiber crops and nuts (Gordon and Davis, 2003). Crop pollination services are being hampered by a decline in the number and diversity of pollinator populations throughout the Hindu Kush Himalayan region (Partap et al., 2001). Pollinator loss in Chitwan has been attributed to habitat loss resulting from misuse of fertilizers and pesticides, reluctant in beekeeping, deforestation, loss of natural vegetation, increased commercial agriculture, use of high yielding varieties and; many other abiotic and biotic factors (Devkota, 2013).

Pollinator friendly practices are those which increase forage for pollinators through mixed crop types over a growing season, planting crop with long flowering period, growing crop with mass flowering, mixed crop types with at least one pollinator attractant crop, greater crop genetic diversity, patches of non crop vegetation, shade tree cultivation, strip cropping, conservation of grass lands etc. Secondly, practices for reducing use of chemicals like selective weeding to conserve weed for pollinators, organic farming, use of less toxic chemicals and less use of inorganic fertilizers are also pollinator friendly practices. The third category of pollinator friendly practices is managing for bee nest sites through no till agriculture, hand tillage, leaving dead trees and fallen branches undisturbed, avoidance of flood irrigation etc. The fourth category of pollinator friendly practices is use of managed pollinators through beekeeping and introducing nesting sites for bee pollinators (FAO, 2008). The present buckwheat production practice under study could be treated as one of the important pollinator friendly practices as it has extended flowering period, mass flowering characteristics, pesticide free production and good forage for bees and other pollinators.

While making production decision, farmers consider costs of production and yield of the crop which ultimately affect rate of adoption and sustainability of any crop. So, profitability study on buckwheat is expected to reveal valuable information relating to farms and farmers growing this crop. However, most of the farmers producing buckwheat lack management techniques, apply inappropriate use of resources, which is mainly due to inadequate knowledge on resource optimization. The future of buckwheat production in the study area depends very much on the awareness of its profitability and resources use efficiency in the context of growing competitive crops in winter season, specially with vegetable crops. Keeping this in view the study was undertaken to determine profitability and resource use efficiency of buckwheat production for the promotion of livelihood of growers and forages for pollinators. 


\section{METHODOLOGY}

\section{STUDY AREA}

The study was conducted at Chitwan district in Nepal where, Global Pollination Project (GPP-FAO) was successfully implemented for five years (2009-2014). Chitwan district is located in the central region of Nepal at geographical line of $20^{\circ} 21^{\prime \prime}$ to $27^{\circ} 46^{\prime \prime}$ "North Latitude and $83^{\circ} 35^{\prime \prime}$ to $84^{\circ} 48^{\prime \prime}$ 'East Longitudes. The climatic situation of the district varies from sub-tropical to tropical giving favorable conditions for growing diverse crop species. Total area of the district is about 223839 ha, of which $25.3 \%$ is agricultural land (DADO, 2014).

Six Village Development Committees (VDCs) namely Padampur and Jutpani from eastern Chitwan; Phulbari and Mangalpur from Central Chitwan; and Meghauli and Sukranagar from Western Chitwan were selected randomly. These VDCs were among the nine VDCs of Global Pollination Project-FAO (GPP-FAO) conducted in the district, for study on pollination management with special focus on best pollination management practices. Western part of Chitwan is more popular in buckwheat production.

\section{SAMPLING METHOD AND DATA COLLECTION PROCEDURE}

Two farmers' group formed under GPP for the promotion of pollination friendly practices, with size of twenty five members in each group were randomly selected from each VDC. Thus a total of 50 farmers from each VDC and 300 farmers in total were the number of farmers selected for study on pollinator friendly agricultural practices. These $\mathbf{3 0 0}$ farmers were studied for ten common pollinator friendly practices namely mustard production, buckwheat production, surface seeded mustard production, surface seeded buckwheat production, organic rice production, organic maize production, bitter gourd production, bee keeping, kitchen gardening and maize cucurbits mix cropping. Among 300 farmers selected under study on pollination friendly practices, 42 were growing buckwheat concentrated in western part of Chitwan. Primary data was collected with the use of structured interview schedule using face to face interview technique in April, 2014.

\section{TECHNIQUES OF DATA ANALYSIS}

After the collection of necessary information it was coded and entered in SPSS data entry sheet and analyzed by using STATA 12 . Collected data were analyzed with descriptive and quantitative methods. The budgeting technique employed in the study was the gross farm income and gross margin. 
Cost, Return and Profitability

All variable inputs like human labor, tractor labor, seed, inorganic fertilizers and organic manures were considered and valued at current market prices of the year 2014 to calculate cost of production.

Total variable cost $=\mathrm{C}_{\text {labor }}+\mathrm{C}_{\text {tractor }}+\mathrm{C}_{\text {seed }}+\mathrm{C}_{\text {fert }}+\mathrm{C}_{\text {manure }}$

Where,

$C_{\text {labor }}=$ Cost on human labor used (NRs. $/$ ha), $C_{\text {tractor }}=$ Cost on tractor labor used (NRs. $/$ ha),

$\mathrm{C}_{\text {seed }}=$ Cost on seed (NRs. $/$ ha), $C_{\text {fert }}=$ Cost on inorganic chemical fertilizers (NRs. $/$ ha) and

$\mathrm{C}_{\text {manure }}=$ Cost on organic manures (NRs. /ha)

Gross return was calculated by multiplying the total volume of main product of buckwheat by the average price at harvesting period (Dillon and Hardaker, 1993). Thus gross return was calculated by using following formula:

Gross return $(\mathrm{NRs} . / \mathrm{ha})=$ Total quantity produced $(\mathrm{kg} / \mathrm{ha}) \times$ Price of buckwheat $(\mathrm{NRs} . / \mathrm{kg})$ Gross margin calculation was done to have an estimate of the difference between the gross return and variable costs. Gross margin was calculated by using the method as given by Olukosi et al. (2006) using following formula;

Gross Margin (NRs. $/$ ha) $=$ Gross return (NRs. $/$ ha) - Total variable cost (NRs. $/$ ha)

Furthermore average cost per Kilogram of buckwheat production was calculated as the ratio of total variable cost (NRs.) to total production $(\mathrm{kg})$. Similarly average gross margin (NRs./kg) was calculated as the ratio of gross margin(NRs./ha) to productivity ( $\mathrm{kg} / \mathrm{ha}$ ).

Benefit cost ratio is the quick and easiest method to determine the economic performance of a business. It is a relative measure, which is used to compare benefit per unit of cost. Undiscounted benefit cost ratio was estimated as a ratio of gross return and total variable cost. Thus, the benefit cost analysis was carried out by using formula;

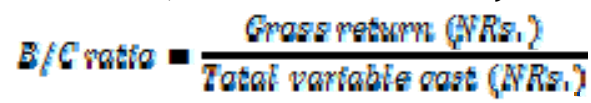

Production Function Analysis

Koutsoyiannis (1977) defined production function as a technical relationship between factor inputs and output. Cobb-Douglas type of production function was used to determine the contribution of different factors on production and to estimate the efficiency of the variable factors of production in buckwheat production. It is most widely used multiplicative and non linear form of production function used in agricultural research and is convenient for the comparison of the partial elasticity coefficient (Prajneshu, 2008). The marginal productivity of factors, marginal rate of substitution and the efficiency of production can be calculated directly from parameters in Cobb-Douglas type of production 
function. Thus, Cobb-Douglas production function of the following form was fitted to examine the resource productivity, efficiency and return to scale.

$\mathrm{Y}=\mathrm{aX}{ }_{1}^{\mathrm{b} 1} \mathrm{X}_{2}^{\mathrm{b} 2} \mathrm{X}_{3}^{\mathrm{b} 3} \mathrm{X}_{4}^{\mathrm{b} 4} \mathrm{e}^{\mathrm{u}}$

Where,

$\mathrm{Y}=$ Gross return (NRs. /ha),

$X_{1}=$ Cost on human Labor (NRs./ha),

$X_{2}=$ Cost on tractor labor (NRs. /ha),

$X_{3}=$ Cost on seed (NRs. /ha),

$X_{4}=$ Cost on sources of plant nutrients (NRs./ha),

$\mathrm{e}=$ Base of natural logarithm,

$\mathrm{u}=$ Random disturbance term,

$\mathrm{a}=$ Constant and

b1, b2, ...., b4=Coefficients of respective variables.

The Cobb-Douglas production function in the form expressed above was linearised in to a logarithmic function with a view of getting a form amenable to practical purposes using Ordinary Least Square (OLS) technique as expressed below;

$\ln Y=\ln a+b_{1} \ln X_{1}+b_{2} \ln X_{2}+b_{3} \ln X_{3}+b_{4} \ln X_{4}+u$

Where,

In= Natural logarithm, and $u=$ Error term

For the calculation of return to scale on buckwheat production, coefficients from CobbDouglas production function was used and calculated using formula;

Return to scale $(\mathrm{RTS})=\Sigma \mathrm{bi}$

Where, $b i=$ Coefficient of $i^{\text {th }}$ explanatory variables.

Return to scale with value greater than unity represents increasing return to scale, value equal to unity represents constant return to scale and vale less than unity represents decreasing return to scale.

Resource Use Efficiency

The allocative efficiency of a resource used was determined by the ratio of Marginal Value Product (MVP) of variable input and the Marginal Factor Cost (MFC) for the input and tested for its equality to one i.e. (MVP/MFC)=1 . Following Goni et al. (2007) the efficiency of resource use was calculated as;

$r=M V P / M F C$

Where, $r=$ Efficiency ratio, $M V P=$ Marginal value product of a variable input and MFC= Marginal factor cost. 
The standard way to examine such efficiency is to compare MVP with the MFC of each variable input. If $M F C_{x_{i}}$ divides $M V P_{x_{i}}$, the result will be equal to the value of $M V P_{x_{i}}$ because MFC at all cases is equal to 1 . As the MFC is price of input per unit, the MFCs of all the inputs will vary while calculating the ratio of MVP to MFC. However, the denominator will always be one, and therefore, the ratio will be equal to their respective MVP (Majumder et al., 2009). The marginal value productivity of a particular resource represents the additional to gross return in value term caused by an additional one unit of that resource, while other inputs are held constant. The most variable, perhaps the most useful estimate of MVP is obtained taking resources, as well as gross return at their geometric means (Dhawan and Bansal, 1977). Since all the variables of the model were measured in monetary value, the slope coefficients of the explanatory variables in the function represent the MVP, which was computed by multiplying the production coefficient (elasticity, in this particular case) of a given resource with the ratio of geometric mean value of output and input variables (Rabbani et al., 2013).

Therefore, $M \mathrm{MP}_{\mathrm{xi}}=\mathrm{dy} / \mathrm{dxi}$, which is the product of regression coefficient with ratio of geometric mean of gross return to the level of use of $i^{\text {th }}$ resource.

According to the conventional neo-classical test of economic efficiency, decision rule for resource use efficiency is that a efficiency ratio $(r)$ equal to unity indicates the optimum use of that factor, the ratio more than unity indicates that gross return could be increased by using more of the resource and the ratio of less than unity indicates the excess use of resource which should be decreased to minimize the loss.

Again, the relative percentage change in MVP of each resource required to obtain optimal resource allocation, i.e. $r=1$ or $M V P=M F C$ was estimated using the following equation below;

$D=(1-M F C / M V P) \times 100$

Or, $D=(1-1 / r) \times 100$

Where, $D=$ absolute value of percentage change in MVP of each resource and $r=$ efficiency ratio (Mijindadi, 1980).

\section{RESULTS AND DISCUSSION}

\section{SOCIO-ECONOMIC CHARACTERISTICS}

The average age of respondents was about 45 years with 7 years of schooling on an average. The average age of respondents' household head was about 52 years with about 5 years of schooling on an average. About $52 \%$ respondents were female and rest $48 \%$ was male among the study population. Family type in the study area was dominated by joint type $(55 \%)$, followed by nuclear $(45 \%)$. The average numbers of male, female and family size was 3.04, 3.36 and 6.40 respectively, and was higher than the national average family 
size 4.5 (CBS, 2011). Most of the respondents were indigenous (57\%) followed by Brahmin/Chhetri (41\%) and others (2\%) which is because of concentrated dwelling of Tharu communities in Buckwheat growing study area. The study revealed that economically active members were about $73 \%$ which was higher than district average of $61.91 \%$ (DDC, 2013). It shows that there is dominancy of young and energetic group of people. Among the economically active population $52 \%$ were engaged in agriculture as primary occupation followed by about $24 \%$ as student. The average land holding of buckwheat growing households was 0.79 ha.

\section{COST OF PRODUCTION}

Human labor was an important and largely used input in the production of buckwheat. It was required for different operations such as land preparation, seed sowing, fertilizer application, harvesting, threshing and cleaning etc. It was computed in terms of man day and converted to monetary term valuating at prevailing wage rate. The cost of human labor in buckwheat production per hectare was estimated at about NRs. 12920 (Table 1). Labor cost accounted about $53 \%$ of total variable cost in buckwheat production. It has shown that buckwheat production activity in the study area is labor intensive. Tractor is labor saving modern tillage technology. In the study area, all the farmers used tractor as tillage equipment for their land preparation. Per hectare costs of tractor was about NRs. 6167 , which accounted about $25 \%$ of total variable cost of buckwheat production. Per hectare costs of organic manures was about NRs. 2312 which constituted $9 \%$ of the total variable cost (Table 1). Major types of organic manures used in the study area were farm yard manure, poultry manure and compost.

Almost all the farmers used chemical fertilizers, mainly urea and DAP. Per hectare costs of inorganic fertilizer was estimated at about NRs. 1760 accounted about $7 \%$ of total variable cost. Buckwheat growers did not use any form of pesticides. Similarly, buckwheat growers did not irrigate their crop as they used to grow buckwheat in unirrigated land with residual moistures after rice or other rainy season crops. As regards the production of buckwheat, the per hectare cost on seed accounted NRs. 1262, which constituted about $5 \%$ of total variable cost of production (Table 1).

Table 1: Average cost of buckwheat production (NRs./ha)

\begin{tabular}{lll}
\hline \multicolumn{1}{c}{ Items of cost } & \multicolumn{1}{c}{ Mean } & \multicolumn{1}{c}{ Percent of total cost } \\
\hline Human labor & 12920.25 & 52.91 \\
Tractor labor & 6166.94 & 25.25 \\
Seed & 1261.59 & 5.17 \\
Organic manure & 2311.90 & 9.47 \\
Inorganic fertilizers & 1759.95 & 7.21 \\
Total cost & 24420.63 & 100.00 \\
\hline
\end{tabular}




\section{RETURNS FROM BUCKWHEAT PRODUCTION}

Farmers in the study area were growing buckwheat on an average at 0.37 hectare of land with per hectare physical volume of output as 9 ton (Table 2). Per hectare gross return was calculated by multiplying the total amount of yield by their respective per unit farm gate price of buckwheat. The average farm gate price of buckwheat was NRs. 34 per kilogram. Per hectare gross return and total variable cost were estimated as NRs. 30601.90 and NRs. 24420.63 , respectively. Per hectare gross margin of buckwheat production was estimated at NRs. 6181.27. Cost and gross margin were also estimated on per kilogram basis and they were estimated at NRs. 27.17 and NRs. 6.86, respectively. It was observed that the overall undiscounted BCR considering total variable cost was 1.25. Thus, it was found that buckwheat production was profitable in the study area.

Table 2: Economic statement of buckwheat production in the study area

\begin{tabular}{lll}
\hline \multicolumn{1}{c}{ Measuring criteria } & \multicolumn{1}{c}{ Average value } \\
\hline Area (ha.) & 0.37 \\
Productivity (t/ha) & 0.90 \\
Average revenue (NRs./kg) & 34.00 \\
Gross return (NRs./ha) & 30601.90 \\
Total cost (NRs./ha) & 24420.63 \\
Gross margin (NRs./ha) & 6181.27 \\
Average cost (NRs./Kg) & 27.13 \\
Average gross margin (NRs./kg) & 6.86 & \\
Benefit cost ratio & 1.25 & Source: Field survey 2014
\end{tabular}

RESOURCE USE EFFICIENCY IN BUCKWHEAT PRODUCTION

Agricultural production is the result of a combination of different inputs used. The individual effect of these inputs can be explained to certain degree by multiple regression analysis, but the isolation of the effect of each variable may be very difficult in tabular technique (Islam and Dewan, 1987). Estimated values of the coefficients and related statistics of Cobb-Douglas production function are shown in Table 3. Four explanatory variables namely human labor cost, tractor use cost, seed cost and nutrient cost were considered to show their effects on production of buckwheat. Out of these four variables tractor cost and nutrient cost were significant at $5 \%$ level. The regression coefficient for tractor cost was 0.562 , which had depicted that with $100 \%$ increase in cost on tractor, gross return could be increased by about $56 \%$, which might be resulted from the higher productivity contributed due to more number of primary tillage. Similar to this, Rabbani et al. (2011) using revenue type of Cobb- Douglas production function resulted power tiller cost as significant factor on mustard production in Bangladesh. Likewise, the regression coefficient for nutrient cost is 0.247 , which had indicated with $100 \%$ increase in nutrient cost, the gross return could be increased by about $25 \%$. 
Table 3: Estimated value of coefficients and related statistics of Cobb-Douglas production function of buckwheat production

\begin{tabular}{lccc}
\hline \multicolumn{1}{c}{ Factors } & Coefficient & Std. Error & t-value \\
\hline Constant & 2.510 & 1.690 & 1.48 \\
Human labor cost (NRs. /ha) & 0.153 & 0.095 & 1.60 \\
Tractor cost (NRs./ha) & $0.562^{*}$ & 0.257 & 2.18 \\
Seed cost (NRs./ha) & -0.098 & 0.131 & -0.74 \\
Nutrient cost (NRs./ha) & $0.247^{*}$ & 0.101 & 2.43 \\
F-value & $19.110^{* *}$ & & \\
R square & 0.673 & & \\
Adjusted R-square & 0.640 & & \\
Return to scale & 0.864 & & \\
\hline
\end{tabular}

Note: **Significant at $1 \%$ level of confidence * Significant at $5 \%$ level of confidence

Source: Field survey 2014

The coefficient of multiple determination $\left(R^{2}\right)$ is a summary measure which tells how well the sample regression line fits the data (Gujarati, 1995). The coefficient of multiple determination $\mathrm{R}^{2}$ of the model was 0.67 for buckwheat production. It indicates that about $67 \%$ of variations in gross return have been explained by the explanatory variables, which were included in the model. The value of adjusted $R$ square was 0.64 indicating that after taking into account the degree of freedom (df) $64 \%$ of the variation in the dependent variable explained by the explanatory variables included in the model. The measures of the overall significance of the estimated regression $\mathrm{F}$ value was 19.11 and it was significant at $1 \%$ level implying that all the explanatory variables included in the model are important for explaining the variation of the dependent variable in buckwheat production.

The concept of return to scale was applied to the production function to determine the stages of production in which farmers were allocating their resources. Returns to scale reflect the degree to which a proportional change in all inputs caused proportional change in the output. The summation of all production coefficients indicate return to scale. The sum of the coefficients of different inputs stood at 0.864 for buckwheat production. This indicates that the production function exhibited a decreasing return to scale implies that if all the inputs specified in the function are increased by $100 \%$ income will increase by about 86\%. Similar to this Wosor and Nimoh (2012) reported decreasing return to scale in chilli pepper production with value 0.304 . Also, Rabbani et al. (2013) reported decreasing return to scale in mustard production with value 0.651 .

The estimated MVP of different inputs used in buckwheat production is presented in Table 4. The study revealed that ratio of MVP to MFC of the human labor cost was positive and less than one which indicated the overuse of this resource. Similarly ratios of MVP to MFC of the tractor cost and nutrient cost were positive and greater than one, indicated their under-utilization. On the other hand, for seed cost the ratio of MVP to MFC was negative 
which demonstrated that it was over-utilized and less profit could be obtained by increasing on seed cost. Study result showed that all the inputs were not utilized to optimum economic advantage. Result agrees with the findings of Goni et al. (2013) and Rabbani et al. (2013).

Table 4: Estimates of measures of allocative efficiency of inputs used in buckwheat production

\begin{tabular}{|c|c|c|c|c|c|c|c|c|}
\hline Inputs & & $\begin{array}{c}\text { Geometric } \\
\text { mean }\end{array}$ & $\begin{array}{c}\text { Coeffic } \\
\text { ient }\end{array}$ & MVP & MFC & $\begin{array}{l}\text { MVP/ } \\
\text { MFC }\end{array}$ & Efficiency & $\begin{array}{c}\text { Percent } \\
\text { adjustmen } \\
\mathrm{t} \text { required }\end{array}$ \\
\hline $\begin{array}{l}\text { Human labor } \\
\text { (NRs./ha) }\end{array}$ & cost & 11092.81 & 0.153 & 0.403 & 1.00 & 0.403 & $\begin{array}{l}\text { Over } \\
\text { utilized }\end{array}$ & -148.311 \\
\hline $\begin{array}{l}\text { Tractor } \\
\text { cost(NRs./ha) }\end{array}$ & & 6042.57 & 0.562 & 2.716 & 1.00 & 2.716 & $\begin{array}{l}\text { Under } \\
\text { utilized }\end{array}$ & 63.176 \\
\hline $\begin{array}{l}\text { Seed } \\
\text { (NRs./ha) }\end{array}$ & cost & 1226.29 & -0.098 & 2.333 & 1.00 & -2.333 & $\begin{array}{l}\text { Over } \\
\text { utilized }\end{array}$ & 142.856 \\
\hline $\begin{array}{l}\text { Nutrient } \\
\text { cost(NRs./ha) }\end{array}$ & & 5878.20 & 0.247 & 1.227 & 1.00 & 1.227 & $\begin{array}{l}\text { Under } \\
\text { utilized }\end{array}$ & 18.500 \\
\hline
\end{tabular}

Source: Field survey 2014

The adjustment in the MVPs for optimal resource use in Table 4 indicated that for optimal allocation of resources, tractor and nutrient cost were required to increase by about $63 \%$ and $19 \%$ respectively. The human labor and seed costs were required to reduce by approximately $148 \%$ and $143 \%$, respectively. A similar result of over utilization of labor and under utilization of fertilizer was assessed by Ibrahim and Ayinde (2011) in the production of hybrid and open pollinated maize in Nigeria. Chapke et al. (2011) also reported that for optimum allocation of resources more than $88 \%$ increase in fertilizer was needed whereas, $127 \%$ reduction was required for seed for sorghum production in India.

\section{CONCLUSIONS}

The study showed that buckwheat production is a reasonably profitable enterprise, although its productivity is still low. Possible reasons for the near to the ground profit are due to less priority of farmer to this crop as compared to other competitive crops, allocation of marginal and unirrigated land for buckwheat production and limited production technologies and; under and over utilization of production inputs. However, higher gross return from per hectare of land can be realized by increasing the level of resources applied to buckwheat production principally tractor power along with manures and fertilizers. The analysis of resource use efficiency on buckwheat production shows that all the resources considered in the study are inefficiently utilized. Thus, to obtain economic advantage, farmers are recommended to reduce primarily labor force and increase use of tractor and nutrients. As buckwheat is exportable and pollinator friendly crop, judicious use of inorganic sources of nutrient is advised. The level of adjustments for use of various resources to earn optimum returns will serve as a bench-mark guideline for the buckwheat growers in the area, government agencies, and agro-based companies. Thus 
if proper uses of resources could be ensured, buckwheat production could be a more viable and attractive commercial enterprise for the promotion of food, income and forage for pollinators.

\section{REFERENCES}

Ahmed, M.S., 2008. Results of farm level socio-economic study on mustard production. Bangladesh Journal of Agricultural Research 13(1): 20-23.

Akter, S. Islam, M.S. and Rahman, M.S., 2011. An economic analysis of winter vegetable production in some selected areas of Narsingdi district. Journal of Bangladesh Agriculture University. 9(2): 241-246.

Aryal, L.N. Thapa, R.B. Tiwari, S. and Chaudhary, N.K., 2014. Effect of insect pollination on growth and yield of buckwheat (Fagopyrum esculentum Moench) in Chitwan, Nepal. International Journal of Research 1(4): 957-964.

CBS, 2011. Population census report. Central Bureau of Statistics, Singha Durbar, Kathmandu Nepal. pp. 120-268.

Chapke, R.R. Mondal, B. and Mishra, J.S., 2011. Resource use efficiency of sorghum production in Rice- fallows in Andhra Pradesh. Indian Journal of Human Ecology 34(2): 87-90.

DADO, 2014. Annual agricultural development program and statistical year book. District Agriculture Development Office, Bharatpur, Chitwan, Nepal.

DDC, 2013. Chitwan district: An introduction. Information and management center, Chitwan, Nepal.

Devkota, K., 2012. Economics of pollination and pollination management practices in Chitwan district, Nepal. M.Sc. thesis, submitted to TU, IAAS, Chitwan, Nepal.

Dhawan, K.C. and Bansal, P.K., 1977. Rationality of the use of various factors of production on different sizes of farm in the Punjab. Indian Journal of Agricultural Economics 32(3): 121-130.

Dillon, J.L. and Hardaker, J.B., 1993. Farm management research for small farm development. Food and Agriculture Organization of the United Nations, Rome.

Eggum, B. O. Kreft, I and Javornik, B., 1981. Chemical composition and protein quality of buckwheat (Fagopyrum esculentum Moench). Plant Foods for Human Nutrition 30:175-179.

FAO, 2008. Tools for conservation and use of pollination services: initial survey of good pollination practices. Food and Agriculture Organization of the United Nations, Rome.

Francischi, M. L. Salfado, J.M. and Leitao, R.F., 1994. Chemical, nutritional and technological characteristics of buckwheat and non-prolamine buckwheat flours in comparison of wheat flour. Plant Foods and Human Nutrition 46: 323-329.

Goni, M. Umar, M. and Sman, U., 2013. Analysis of resource-use efficiency in dry season vegetable production in Jere Borno State, Nigeria. Journal of Biology and Agriculture Health 3(19): 18-23.

Gordon, J. and Davis, L. 2003. Valuing honeybee pollination. Rural Industries Research and Development Corporation. Publication no. 03/077.

Gujarati, D.N., 2007. Basic Econometrics. Tata McGraw-Hill Ltd, New Delhi, India.

Ibrahim, U. and Ayinde, B.T., 2011. Efficiency of resource use in hybrid and open pollinated maize production in Giwa Lga of Kaduna State, Nigeria. Libyan Agriculture Research Center Journal International 2(5):215-220.

Islam, M.S. and Dewan, S., 1987. An economic analysis of pond fish production in some selected areas of Bangladesh. Bangladesh: Bureau of Socioeconomic Research and Training, Bangladesh Agricultural University, Bangladesh.

Koutsoyiannis, A., 1977. Theory of Econometrics. London: The MacMillan Press Ltd., London 
Majumder, M.K. Mozumdar, L. and Roy, P.C., 2009. Productivity and resource use efficiency of Boro rice production. Journal of Bangladesh Agricultural University 7(2):247-252.

Mijindadi, N.B., 1980. Production efficiency on farms in northern Nigeria. PhD dissertation submitted to Cornell University, USA.

MoAD, 2012. Statistical Information on Nepalese Agriculture 2010/2011. Ministry of Agriculture Development. Agribusiness Promotion and Statistics Division(ABPSD), Kathmandu, Nepal.

Olukosi, J.O. Isitor, S.U. and Ode, M.O., 2006. Introduction to agricultural marketing and prices: principle and application. American Journal of Agriculture and Forestry 2(4): 199-205.

Partap, T., 2001. Mountain agriculture, marginal land and sustainable livelihoods: Challenges and opportunities. International Symposium on Mountain Agriculture in HKH Region (21-24 May, 2001). ICIMOD, Kathmandu, Nepal.

Prajneshu, 2008. Fitting of Cobb-Douglas production functions: revisited. Agricultural Economics Research Review 21:289-292.

Rabbani, M.G. Sheema, A.A. Islam, M.S. and Hasan, H.K., 2013. Profitability and resource use efficiency of mustard production: evidence of farmers' practices in Mymensingh District of Bangladesh. International Journal of Applied Research in Business Administration and Economics 2(3): 37-46.

Rajbhandari, B.P., 2010. Buckwheat in the land of Everest. Himalayan College of Agricultural Sciences and Technology (HICAST), Kathmandu, Nepal.

Wosor, D.K. and Nimoh, F., 2012. Resource use efficiency in chili pepper production in the Keta municipality of Volta Region of Ghana. Journal of Elixir Production Management 47: 8595-8598. 